\title{
RITUAL DEPOSIT OF THE SARMATIAN AGE FROM THE BARROW ON THE LOWER DON BASIN
}

\author{
Mikhail V. Vlaskin \\ State Autonomic Cultural Facility of Rostov Region "The Don Heritage", Rostov-on-Don, Russian Federation
}

\author{
Aleksandr V. Symonenko \\ Institute of Archaeology, National Academy of Sciences of Ukraine, Kyiv, Ukraine
}

\begin{abstract}
Introduction. In 2007 the archaeological expedition of the State Autonomic Cultural Facility of Rostov Region "The Don Heritage" excavated burial ground Krasny IV in Aksay district of Rostov Region. In the mound of barrow No. 13 a bronze rod-shaped frontlet plate with a hook, a bronze lunula-shaped harness pendant, six bronze bridle roundels, a bone cheek-piece, and iron fragments of the, most likely, bits have been discovered. Methods and materials. In the study the standard methods of archaeological analysis are used: comparative-typological, the method of analogies, chronological, and cartographic ones. The materials are the discovered artifacts. Analysis. According to the conditions of location and composition, the assemblage from barrow No. 13 can be identified as a ritual deposit. Such assemblages are known in special literature as "hoards", "strange assemblages" or "votive hoards". They have been found in mounds of barrows or in natural hills without traces of human burials. Usually they consist of cauldrons or situlae (often the rest items are put into them), bridle sets with peculiar frontlet plate with a hook, silver and bronze phalerae, helmets of Western types, weapons (most often spear- and arrowheads), expensive and socially prestigious items (silver and glassware, jewelry). The presence of all these items in the ritual deposit is not necessary. These sites are concentrated in geographically opposite regions: the basins of the Southern Bug, Dniester and Prut and in the east of European Sarmatia - in the AzovDonbass, Don and Kuban basins, the Lower Volga basin and North Caucasus. Results. Close parallels to the frontlet plate, bronze lunula-shaped pendant, and bridle roundels were found in the South Bug basin (Marievka), the Dniester and Prut interfluve (Brãviceni), Romania (Zimnicea), the North Caucasus (Prochnookopskaya, Geymanovsky, Giaginskaya), the Don and Volga interfluve (Kachalinskaya). All of these sites are identified as ritual deposits of the late $2^{\text {nd }}-1^{\text {st }}$ centuries BC. The assemblage from barrow No. 13 should be dated to the same time. The ritual deposits of Eastern Europe could be divided into two chronologically different groups. The sites of the early group ( $3^{\text {rd }}-$ early $2^{\text {nd }}$ century BC) have appeared in the North Caucasus and concentrated in the North-Western Pontic region. It is assumed that they belong to the Xsaiai, Saudaratai and Thissamatai mentioned in the Olbian decree in honor of Protogenes. The sites of the late group (the late $2^{\text {nd }}-1^{\text {st }}$ centuries BC) in the Northern Pontic Region, the Don basin, the North Caucasus and adjacent territories belong, most likely, to the Sarmatians.
\end{abstract}

Key words: ritual deposit, barrow, assemblage, frontlet plate, Sarmatians, Northern Pontic region, Northern Caucasus.

Citation. Vlaskin M.V., Symonenko A.V. Ritual Deposit of the Sarmatian Age from the Barrow on the Lower Don Basin. Vestnik Volgogradskogo gosudarstvennogo universiteta. Seriya 4. Istoriya. Regionovedenie. Mezhdunarodnye otnosheniya [Science Journal of Volgograd State University. History. Area Studies. International (i. Relations], 2020, vol. 25, no. 4, pp. 151-167. (in Russian). DOI: https://doi.org/10.15688/jvolsu4.2020.4.10

УДК 930.26(470+571):726

Дата поступления статьи: 28.03.2020

ББК 63.48(2)-427.1 Дата принятия статьи: 08.04.2020

\section{РИТУАЛЬНЫЙ ДЕПОЗИТ САРМАТСКОГО ВРЕМЕНИ ИЗ КУРГАНА НА НИЖНЕМ ДОНУ}

\author{
Михаил Васильевич Власкин
}

Государственное автономное учреждение культуры Ростовской области «Донское наследие», г. Ростов-на-Дону, Российская Федерация 


\section{Александр Владимирович Симоненко}

Институт археологии Национальной академии наук Украины, г. Киев, Украина

Аннотация. Введение. В 2007 г. археологическая экспедиция ГАУК РО «Донское наследие» проводила исследования курганного могильника Красный IV в Аксайском районе Ростовской области. В насыпи кургана 13 обнаружены бронзовый стержневидный налобник с крючком, бронзовая дуговидная пластина с железными петлями на обороте, шесть бронзовых уздечных блях, костяной псалий, фрагменты железа - вероятно, остатки удил. Методы и материальы. При исследовании были использованы стандартные методы археологического анализа: сравнительно-типологический, метод аналогий, хронологический, картографический. Материалами являются исследуемые артефакты. Анализ. Комплекс из к. 13 по условиям залегания и составу может быть определен как ритуальный депозит. Такие комплексы известны в литературе как «клады», «странные комплексы» или «вотивные клады». Они найдены в насыпях курганов или в естественных возвышенностях без следов человеческого погребения. Обычно в их состав входят котлы или ситулы (часто в них и сложены остальные вещи), уздечные наборы со своеобразными налобниками с крючком, серебряные и бронзовые фалары, импортные шлемы западных типов, оружие (чаще всего наконечники копий и стрел), дорогие и социально престижные вещи (серебряная и стеклянная посуда, украшения). Наличие в составе ритуального депозита всех перечисленных вещей не обязательно. Эти памятники концентрируются в географически противоположных регионах: бассейнах Южного Буга, Днестра и Прута и на востоке Европейской Сарматии - в Приазовье-Донбассе, на Дону и Кубани, есть отдельные находки в Нижнем Поволжье и на Северном Кавказе. Результаты. Близкие аналоги налобнику, бронзовой пластине и уздечным бляхам найдены в Нижнем Побужье (Марьевка), междуречье Днестра и Прута (Брэвичень), Румынии (Зимнича), на Северном Кавказе (Прочноокопская, Геймановский, Гиагинская), в междуречье Дона и Волги (Качалинская). Все перечисленные комплексы признаны ритуальными депозитами конца II - I в. до н. э. Этим же временем должна датироваться находка в к. 13. Ритуальные депозиты Восточной Европы составляют две хронологически различные группы. Памятники ранней группы (III - начало II в. до н. э.) появляются на Северном Кавказе и концентрируются в Северо-Западном Причерноморье. Предполагается, что они оставлены упомянутыми в ольвийском декрете в честь Протогена сайями, савдаратами и фиссаматами. Памятники поздней группы (конец II - I в. до н. э.) в Северном Причерноморье, на Дону, Северном Кавказе и сопредельных территориях, скорее всего, были оставлены сарматами. Вклад авторов. М.В. Власкин руководил раскопками памятника и составил его описание. А.В. Симоненко проанализировал материал, подобрал аналогии и осуществил типолого-хронологический анализ.

Ключевые слова: ритуальный депозит, курган, комплекс, налобник, сарматы, Северное Причерноморье, Северный Кавказ.

Цитирование. Власкин М.В., Симоненко А.В. Ритуальный депозит сарматского времени из кургана на Нижнем Дону // Вестник Волгоградского государственного университета. Серия 4, История. Регионоведение. Международные отношения. -2020. - Т. 25, № 4. - C. 151-167. - DOI: https://doi.org/10.15688/jvolsu4.2020.4.10

Введение. Среди памятников юга Восточной Европы сарматского времени есть группа своеобразных находок, известных в литературе под названиями «клады», «странные комплексы», «вотивные клады» или «ритуальные депозиты». Эти комплексы найдены в насыпях курганов или в естественных возвышенностях без следов погребения. В их состав входят котлы или ситулы (часто в них и сложены остальные вещи), уздечные наборы со своеобразными налобниками с крючком, серебряные и бронзовые фалары, импортные шлемы западных типов, оружие (чаще всего наконечники копий и стрел), дорогие и социально престижные вещи (серебряная и стеклянная посуда, украшения) ${ }^{1}$.
В свое время их рассматривали как принадлежащие поздним скифам [8; 27]. Затем появились веские основания считать эти памятники сарматскими $[16$, с. $57 ; 18$, с. $18 ; 24$, с. 124 ; 25 , c. $85-87 ; 28$, c. $90 ; 36$, c. $69 ; 39$, c. $97 ; 42$, p. 41 ; 43, S. 469]. Некоторые исследователи ставят под сомнение их сарматскую принадлежность [9, c. $94 ; 12$, с. $70-71 ; 22$, с. $143 ; 37$, с. 998$]$.

Эти памятники концентрируются в географически противоположных регионах: бассейнах Южного Буга, Днестра и Прута и на востоке Европейской Сарматии - в Приазовье-Донбассе, на Дону и Кубани, есть отдельные находки в Нижнем Поволжье и на Северном Кавказе. Стабильный набор предметов, связанный с воинским обиходом, отсутствие 
останков человека и нахождение в кургане либо естественной возвышенности заставляют предположить их культовое (поминальное либо жертвенное) назначение [23].

В последние годы такие ритуальные депозиты попадаются археологам все чаще, а иногда, к сожалению, появляются на онлайнаукционах как добыча грабителей.

Методы и материалы. При исследовании были использованы стандартные методы археологического анализа. Сравнительнотипологический метод и метод аналогий позволили определить круг параллелей артефактам из кургана 13. Датировка вещей комплекса была определена хронологическим методом и методом «узких» и «широких» датировок. Картографический метод установил круг подобных памятников и привел к определенным историческим выводам. Материалами являются исследуемые артефакты.

Анализ. В 2007 г. археологическая экспедиция ГАУК РО «Донское наследие» проводила исследования курганного могильника Красный IV в Аксайском районе Ростовской области. Работы велись по Открытому листу № 1312 (форма 4) от 27.08.2007 г., выданному на имя С.А. Науменко.

В северо-восточном секторе насыпи кургана 13 эпохи раннего железа на расстоянии 7,80 м к СЗС от условного 0 (рис. 1,2 ) на глубине -43 обнаружено скопление следующих предметов:

1. Бронзовый стержневидный налобник с крючком, согнутый под прямым углом. Стержень длинный, массивный, округлый в сечении. Примерно посередине имеется перехват, после которого толщина стержня несколько больше, чем в верхней части. Крючок кольцевидный, незамкнутый, закругленный конец подчеркнут врезным перехватом. Ниже крючка - овальное вертикальное расширение (здесь и далее названное петлей) с круглым отверстием. Ниже перехода петли в корпус - поясок из трех врезных линий. Три таких же пояска украшают утолщенную часть корпуса - по краям и в центре. Общая длина $-18,5$ см, длина утолщенной части 8 см, сечение - 0,45-0,6 см, размер петли $2,7 \times 1,4 \mathrm{~cm}$, толщина ее $-0,2-0,32 \mathrm{~cm}$, диаметр отверстия - 0,7 см, размеры крючка $2,6 \times 2,2 \mathrm{~cm}$, сечение - 0,4 см, ширина орна- ментальных насечек - 0,5-0,6 см, № $235^{2}$ (рис. 2,1 , рис. 3,1 , рис. 4,6 ).

2. Бронзовая дуговидная пластина с прямо срезанными концами, один из которых обломан. В сечении ступенчатая, по центру - треугольное в сечении ребро. Рельеф выдавлен с тыльной стороны. В центре пластины - четыре бронзовых заклепки, по две с каждой стороны ребра, с помощью которых крепились две железные пластинчатые горизонтальныепетли. Длина пластины по дуге - 18,4 см, ширина по центру $-4,1$ см, на концах $-3,1$ и $2 \mathrm{~cm}$, толщина $-0,1 \mathrm{~cm}$, длина петель $-4,3$ и 3,6 см, ширина $-0,75-0,8$ см, № 228 (рис. 2,2, рис. 3,1 , рис. $4,6 a$ ).

3. Шесть бронзовых блях с широкими плоскими краями и полусферическим умбоном в центре. С внутренней стороны по диаметру двумя заклепками закреплены пластинчатые петли, выгнутые посередине. В одном случае сохранилась бронзовая петля (№ 229), в остальных случаях петли были железные и уцелели лишь на горизонтально отогнутых краях (№ 230-234). Диаметр блях - 3,9 см, высота варьирует в пределах 1,8-1,3 см, диаметр умбона $-2,4$ см, ширина края $-0,6$ см, ширина петли $-0,8$ см, толщина стенок 0,1 см (рис. 2, 3-6, рис. 3, 1 ).

4. Костяной стержневидный псалий с невыразительным 8-видным утолщением в центральной части, где расположены два сквозных отверстия. Сечение подпрямоугольное. Концы псалия слегка утолщены. Длина 9,7 см, ширина $-0,65$ см $(0,8$ см на концах $)$, ширина в центре - 1,1-1,3 см, диаметр отверстий $-0,5-0,65 \mathrm{~cm}$, сечение $-0,6 \times 0,45 \mathrm{~cm}$ $(0,4 \times 1,1$ см в центре), № 236 (рис. 2, 7, рис. 3,1$)$.

Здесь же зафиксированы мелкие фрагменты железного предмета, возможно остатки удил (№ 239), мелкие фрагменты костяного предмета (№ 237-238) в виде узкой пластинки с закругленным с одной стороны концом (второй псалий?).

По условиям находки - в насыпи кургана, компактное скопление предметов (рис. 1,2 ), отсутствие человеческих костей комплекс можно определить как ритуальный депозит («клад», «вотивный клад»). Этот комплекс упомянут в сводке В.П. Глебова в группе 1 «Клады», найденные в насыпях курганов $[4$, c. 148$]$. 
Обнаруженный здесь налобник по конструкции и форме принадлежит своеобразной группе налобников с крючком [27]. В этой группе по форме корпуса выделено несколько типов: с топоровидной лопастью, стержневидные, с узкой подтреугольной лопастью, с овальной лопастью и с фигурной лопастью [11, c. $136 ; 29$, с. $83-85 ; 33$, с. $255-260]$.

Налобник из Красного IV относится ко 2-му типу - он стержневидный [33, с. 258]. Изделия этого типа найдены в Марьевке, Брэвичень, Веселой Долине, Зимниче (СевероЗападное Причерноморье), есть находки на Северо-Западном Кавказе (станица Прочноокопская, курган в имении Зиссерманов у Геймановского поселка). Каждый из этих налобников при единстве формы в деталях индивидуален.

Бронзовый налобник из Марьевки имеет корпус в виде прямого, круглого в сечении стержня, несколько расширяющегося посередине. Нижний конец корпуса оканчивается диском, верхний - загнут кольцом, заканчивающимся биконической кнопкой. В месте перехода корпуса в кольцо - овальное расширение (петля) с круглым отверстием посередине. Под петлей передняя часть корпуса украшена рельефным орнаментом - тремя секциями поперечных тройных насечек, разделенных канавками. Над дисковидным окончанием корпуса такой же декор из четырех секций, две из которых состоят из двух и пяти насечек, а две - из четырех. Длина налобника -21 см (рис. 4,1$)$. Хранится в ГМИИ им. А.С. Пушкина, инв. № II 1е 2959.

Бронзовый налобник из Брэвичень ${ }^{3}$ выглядит однотипным марьевскому - прямой стержневидный корпус слегка утолщен посередине, заканчивается конической кнопкой. Однако первоначально средняя часть корпуса была плоской, а затем ковкой свернута в трубку, создающую утолщение. В верхней части корпуса: округлая петля с круглым отверстием; выше нее корпус загнут в кольцевидный крючок, конец которого оформлен биконической кнопкой. Верхняя часть корпуса ниже петли украшена врезными косыми насечками; нижняя часть (выше кнопки, до петли) декорирована подобно марьевскому - тремя секциями поперечных насечек, разделенных канавками. Длина налобника - 19,5 см (рис. 4, 2). Хранится в НМИМ [34].
Корпус и крючок железного налобника из Веселой Долины обломаны, а петля образована кольцевым расширением верхней части корпуса.

В погребении у станицы Прочноокопской $[1$, с. 209 , рис. 3,$1 ; 2$, с. 54 , рис. 5,21$]$ найдена верхняя часть бронзового стержневидного налобника (рис. 4, 3) с кольцевой петлей. Под ней корпус украшен тремя поясками тройных горизонтальных насечек. Судя по сходству орнаментации, прочноокопский налобник близок марьевскому.

К северо-востоку от Прочноокопской в кургане у пос. Геймановский $[6$, с. 95 , рис. 1,5$]$ был также обнаружен бронзовый стержневидный налобник (рис. 4, 4).

Еще одно изделие этого типа происходит из конской могилы гетского некрополя Зимнича в Румынии [41, p. 77, fig. 7, 5, fig. 8, 5]. Как и у других, верхний и нижний концы корпуса зимничского налобника орнаментированы насечками, а петля оформлена острыми выступами по верхнему краю (рис. 4, 5). Крючок разогнут, но, без сомнения, был кольцевидным.

Как видно, прямого аналога налобнику из Красного IV среди известных науке нет, но общие параметры не оставляют сомнения в том, что он относится к описанному типу.

Происхождение, хронология и ареал налобников с крючком. Прототипами налобников с крючком являются аналогичные украшения скифской узды V-IV вв. до н. э. При близости по форме ранние налобники гораздо меньше. Стержневидные найдены в Частых курганах и Таврической губернии, изделия с топоровидной и овальной лопастью - в Среднем Подонье, Поднепровье и на Каменском городище [33, с. 261].

Свой поздний облик, анализируемый здесь, налобники с крючком приобрели во второй половине III в. до н. э. Судя по находкам наиболее ранних образцов в Тираспольских курганах, тип с топоровидной лопастью сформировался в позднескифской среде. Об изготовлении таких налобников в Неаполе Скифском говорит найденная там литейная форма из ручки родосской амфоры (рис. 5,1$)$. Она в какой-то мере соответствует налобнику из Великоплоского (рис. 5, 2), лишь край лопасти иной. Скорее всего, он доделывался ковкой. 
Хронология таких налобников охватывает несколько веков и стала предметом активной дискуссии. В свое время их датировали III-I [27, с. 242] или II-I вв. до н. э., отдавая предпочтение последнему столетию [21, с. 64-65]. После находок в Тираспольских курганах заговорили о дате III-II вв. до н. э. как для налобников, так и для «кладов» СевероЗападного Причерноморья, связывая их теперь с населением, оставившим эти курганы $[7$, c. $58-59 ; 9$, с. $94 ; 10$, с. $150 ; 12$, с. $70-71 ; 40$, c. 15-16]. Наверное, не стоит быть столь категоричными: этот вопрос не прост и требует анализа каждой из его составляющих. Тираспольские курганы с налобниками с топоровидной лопастью уверенно датируются последней третью III - первой четвертью II в. до н. э. родосскими и синопскими амфорными клеймами и фибулами среднелатенской схемы [37, c. $965 ; 40$, с. 16$]$.

Налобники с топоровидной лопастью до последнего времени были известны только в Северо-Западном Причерноморье ${ }^{4}$. Несколько иную картину демонстрируют стержневидные налобники. Два экземпляра происходят с Северного Кавказа, один - из соседнего нижнедонского региона, а комплексы из Марьевки, Веселой Долины, Брэвичень и Зимничи находятся далеко на западе.

Реконструировать историю налобников с крючком можно следующим образом. Они появились во второй половине III в. до н. э. как результат эволюции исходных скифских форм V-IV вв. до н. э. В Северном Причерноморье базовыми формами стали топоровидная и узкая лопасти. В течение II в. до н. э. с этими налобниками познакомились соседи поздних скифов - сарматы, возможно, меоты и синды (находки в курганах на азиатской стороне Боспора и Северном Кавказе), и они стали деталью узды раннесарматского культурного круга, обогатившись новыми формами.

Одним из интереснейших предметов комплекса является дуговидная пластина (рис. 2,2 , рис. 3,1 ). Горизонтальные петли на обороте в ее центральной части говорят о том, что она подвешивалась либо крепилась на вертикальном ремне. Такие предметы найдены в Поволжье, на Северном Кавказе и в Северо-Западном Причерноморье. Ю.П. Зайцев по форме и сечению разделил эти изделия на пла- стинчатые и U-образные [11, с. 136-137], здесь названные двумя типами.

Tun 1 - узкая скоба с длинными ветвями (Марьевка, Прочноокопская, Ханкальское городище) ${ }^{5}$.

В Марьевке бронзовая скоба была согнута из полутрубки с толщиной стенки 2 мм. Концы ее свернуты в стержни и орнаментированы секциями тройных валиков, образованных врезными линиями. Завершаются они дисковидными окончаниями. В центре верхней части скобы изнутри вставлена пластинка с чуть загнутыми краями, согнутая в центре в П-образную петлю. Она соединена со скобой заклепками с высокими коническими головками (сохранилась одна). Длина изделия (по концам ветвей) - 17 см, ширина $-11,4$ см (рис. $4,1 a$ ). Скоба найдена вместе со стержневидным налобником.

Практически тождественная бронзовая скоба (рис. 4, 3a) была найдена на конском черепе в Прочноокопской $[2$, с. 209 , рис. 3,1$]$. Совпадают размеры, орнаментация, лишь петля не П-образная, а трапециевидная, и не сохранились заклепки. Примечательно, что и в этой могиле скоба найдена вместе со стержневидным налобником.

Еще одна подобная вещь происходит из «клада», обнаруженного в культурном слое II Ханкальского городища в Чечено-Ингушетии $[20$, с. 257 , рис. 1,1$]$. Она отличается от марьевской и прочноокопской находок меньшей глубиной полутрубки и слегка уплощенной внешней стороной; в сечении она близка к П-образной (рис. 4, 7a). И здесь в составе убора присутствует налобник, но с фигурной лопастью (рис. 4, 7).

Tun 2 - литая плоская дуговидная пластина с выпуклой внешней стороной. Концы и края пластин могут быть декорированы различными элементами (Гиагинская, Красный IV, Качалинская, Зимнича, Тырнава).

Из станицы Гиагинской в Адыгее происходит бронзовая дуговидная пластина с центральным ребром [14, кат. 132, с. 143 , фото на с. 228]. В центре самой широкой части на внутренней поверхности двумя заклепками с выступающими головками была закреплена горизонтальная петля. Заостренные концы пластины увенчаны головками животных (рис. 4, 8). 


\section{АРХЕОЛОГИЯ РАННЕГО ЖЕЛЕЗНОГО ВЕКА}

В составе «клада» из станицы Качалинской в междуречье Дона и Волги - две бронзовых серповидных пластины с горизонтальными петлями на обороте [26, с. 152, рис. 5]. Интересно, что они орнаментированы в одном стиле с бронзовыми налобниками с крючком, найденными тут же, и составляют гарнитур (рис. 4, 9a-10a).

Дуговидная пластина П-образного сечения с горизонтальной петлей на обороте (рис. $4,5 a$ ) и стержневидный налобник с крючком происходят из конского погребения 13 гетского некрополя в Зимниче на Балканах [41, p. 77, fig. 7, 5, fig. 8, 5].

В кургане у с. Тырнава в Болгарии в составе комплекса вооружения и конского снаряжения среднелатенского времени была найдена бронзовая пластина в форме лунницы с концами, украшенными шариками [13, с. 137 , рис. 2 , 2; 38 , рис. 36]. Ю.П. Зайцев приводит невнятное описание подобного предмета в полевом дневнике раскопок Ногайчинского кургана [13, с. 138]. Если эта вещь действительно является пластиной исследуемого типа, то здесь мы имеем еще один случай совместной находки «лунницы» и налобника с крючком.

Морфологические признаки (форма, наличие и расположение петель на обороте, сопровождение) позволяют отнести пластину из Красного IV к анализируемым вещам. Она не имеет прямых аналогов в этом ряду, но сечением близка пластине из Зимничи. Дуговидные пластины всегда найдены вместе с деталями узды. В Прочноокопской и Зимниче такие скобы in situ располагались у черепа лошади.

Ю.П. Зайцев считает их подвесками упряжи [11, с. 136-137] либо частью полукруглого «султана» или плюмажа, изображенного на пергамском рельефе [13, с. 140]. Признаться, место обсуждаемых предметов в этом уборе не совсем понятно.

В свое время один из авторов предположил, что такие скобы и пластины были налобниками [31, с. 215; 32, с. 378] либо служили украшением науза - ременного ошейника, на котором подвешивались амулеты-обереги и декоративные кисти [32, с. 378; 33, с. 269-270]. Вероятно, ближе к истине последнее предположение - версия с налобником была ошибочной. Подвеска науза могла вполне оказаться рядом с конским черепом, когда ошейник перемещался при укладке трупа лошади в могилу. О том, что это подвеска может свидетельствовать расположение петли - она рассчитана на ремень, идущий сверху вниз.

Примечательно, что анализируемые предметы почти всегда найдены с налобниками с крючком (стержневидными и фигурными) ${ }^{6}$. Скобы из Марьевки и Прочноокопской, пластины из Качалинской и налобники из этих комплексов одинаково орнаментированы, составляя как бы гарнитур.

Шесть уздечных блях по форме и размерам аналогичны таким же бляхам из «кладов» в Прочноокопской (см. рис. 5, 3), Брэвичень, Качалинской (рис. 5,4$)$, за одним исключением: перечисленные бляхи имеют отверстие в центре умбона и не имеют петель. Таким образом, они являются, скорее, ворварками [33, с. 240 , рис. 85, 7-9]. Практически аналогичные серебряные бляхи без отверстий (рис. 5, 5), у которых умбон несколько ниже, чем в Красном IV, найдены в одном комплексе с псалиями раннесарматского облика (коллекция Платар). Перстневидная бляшка из этой находки (рис. 5,6 ) аналогична найденным в большом кургане $1 \mathrm{Ba}-$ сюринской горы (рис. 5, 7).

Близкая по форме и размерам бронзовая бляха с невысоким умбоном происходит из раскопок Б.Н. Гракова 1928 г. в с. Нежинском, группа Горбатый мост, к. 4, п. 3 (рис. 5, 8). М.Г. Мошкова датировала памятник IV-III вв. до н. э. [17, табл. $21,7,8]$. А.С. Скрипкин включил этот пункт в список памятников IIIІ вв. до н. э. [35, с. 133, № 15]. Здесь бляха также найдена вместе с двумя перстневидными бляшками (рис. 5, 9). Большинство находок таких бляшек датировано различными годами III в. до н. э.: Глиное, к. 97, п. 2 - вторая четверть III в. до н. э., к. 14, п. 1. - последнее десятилетие III в. до н. э. [37, с. 948, 951]; «клад» из Дебальцево - середина III в. до н. э. $[15$, с. 232]; Васюринская гора, к. 1. - III [3, с. 280] или II в. до н. э. [30, с. 602]; Великоплоское - конец ІІІ в. до н. э. [8, с. 158]. Но металлические элементы конской узды долговечны и могли использоваться не одно десятилетие. Поэтому мы не исключаем и II в. до н. э. как дату находки из группы Горбатый мост.

Костяной стержневидный двудырчатый псалий не имеет точной даты. Псалии этого 
типа бытовали с первой половины IV в. до н. э. (Алебастрова гора, к. 3) до I в. н. э. (Новогригорьевка, к. 1, п. 17) [28, с. 39 , рис. $10,3 B]$. Надо думать, изготовить подобный псалий мог любой всадник из подручного материала в любые времена.

Приведенные аналогии позволяют определить более или менее узкую дату комплекса. Наиболее вероятная дата Марьевки - конец II - первая половина I в. до н. э. [43, S. 484]. Этим же временем, с предпочтением первой половины I в. до н. э. [41, p. 77], датировано конское погребение в Зимниче. Синхронен им комплекс из Брэвичень [34]. II в. до н. э. датировали погребение в Прочноокопской авторы публикации [1, с. 208], но сходство его предметов с марьевскими позволяет расширить возможный диапазон до первой половины I в. до н. э. Погребение на участке Зиссерманов датировано концом III - началом II в. до н. э. [6, с. 95], однако наличие в комплексе маленького втульчатого наконечника стрелы не исключает и более позднюю дату. «Клад» из Качалинской с аналогичными уздечными бляхами датирован концом II - началом или первой половиной I в. до н. э. [26, с. 157]. Приведенные аналогии позволяют считать комплекс из могильника Красный IV ритуальным депозитом («вотивным кладом», «странным комплексом») и датировать его концом II первой половиной І в. до н. э.

В последние годы возникла дискуссия о хронологии и этнической принадлежности ритуальных депозитов. Их связывают с сарматами, поздними скифами, есть точка зрения о внеэтническом характере «кладов» (библиографию вопроса см.: [12, с. 67-68]). Поскольку один из авторов является активным участником этой дискуссии и планирует принять в ней дальнейшее участие, здесь мы ограничимся кратким изложением своей позиции.

В ходе дискуссии получены убедительные доказательства отсутствия хронологической и этно-культурной монолитности ритуальных комплексов - не все они относятся к эпохе Митридатовых войн и оставлены исключительно сарматами. Предварительно можно разделить известные памятники этого типа на две хронологические группы. Памятники ранней группы (III - начало II в. до н. э.) появляются на Северном Кавказе (ст. Пластуновская), а концентрируются в Северо-Западном Причерноморье. Предполагается, что они оставлены сайями или савдаратами и фиссаматами, упомянутыми в ольвийском декрете в честь Протогена. Памятники поздней группы (конец II I в. до н. э.) в Северном Причерноморье, на Дону, Северном Кавказе и сопредельных территориях, скорее всего, были оставлены сарматами. Детальное обоснование этой гипотезы - тема отдельной работы.

Благодарности. Авторы выражают благодарность С.А. Науменко за предложение опубликовать находку; Б.А. Раеву, Виталие Быркэ и Валериу Бубуличу за любезно предоставленную информацию о неопубликованных аналогах; с признательностью мы вспоминаем рано ушедшую из жизни Н.Е. Беспалую - автора рисунков комплекса.

\section{ПРИМЕЧАНИЯ}

${ }^{1}$ Попытку систематизировать эти комплексы по условиям находки сделал В.П. Глебов [4].

${ }^{2}$ Номера по полевой описи находок.

${ }^{3}$ Вещи из Брэвичень считались утраченными. Недавно они были найдены в Национальном музее истории Молдовы и подготовлены к публикации [34].

${ }^{4}$ Недавно такие налобники были обнаружены на противоположных концах ойкумены - в Закубанье, в Новолабинском могильнике и в Трансильвании при раскопках могильника Альба Юлия.

5 Окончание одной ветви скобы этого типа найдено в святилище на Гурзуфском Седле [19, с. 133 , рис. 65,14$]$.

${ }^{6}$ На сайте аукциона Виолити в 2016 г. было вывешено фото комплекса, добытого грабителями якобы в Днепропетровской области, где аналогичная гиагинской пластина найдена вместе с налобником с крючком (рис. 3, 2). На сайте указано, что комплекс найден в ситуле, судя по фотографии, типа Баргфельд.

7 В.П. Глебов аргументированно и, на наш взгляд, верно датировал фибулу и весь «клад» из Дебальцево I в. до н. э. [5, с. 54].

\section{СПИСОК СОКРАЩЕНИЙ}

ГМИИ им. А.С. Пушкина - Государственный музей изобразительного искусства имени А.С. Пушкина.

НМИМ - Национальный музей истории Молдовы. 


\section{ПРИЛОЖЕНИЕ}
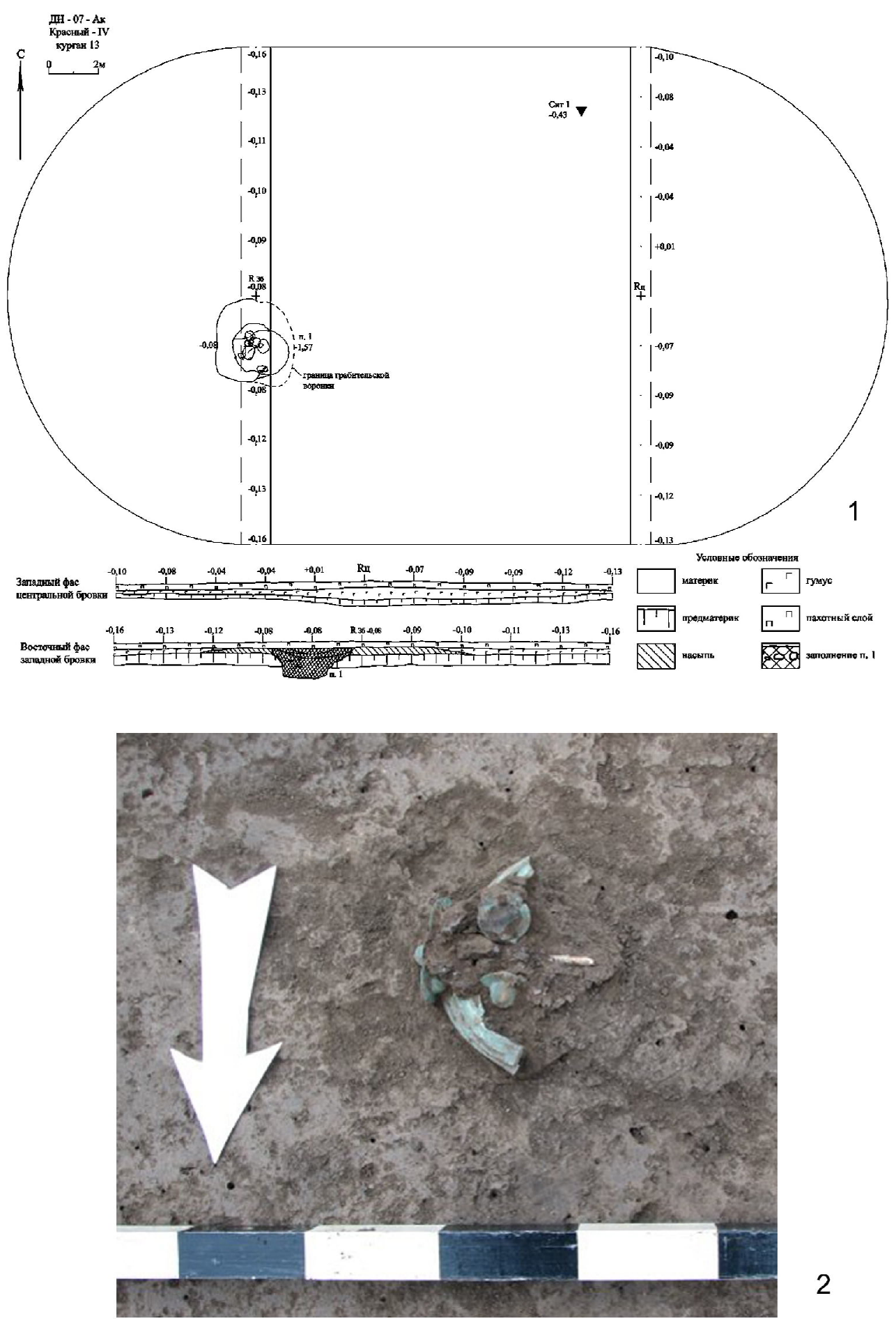

Рис. 1. Курган 13, ситуация 1:

1 - общий план кургана; 2 - ситуация 1

Fig. 1. Barrow 13, situation 1:

1 - plan of the barrow; 2 - situation 1 


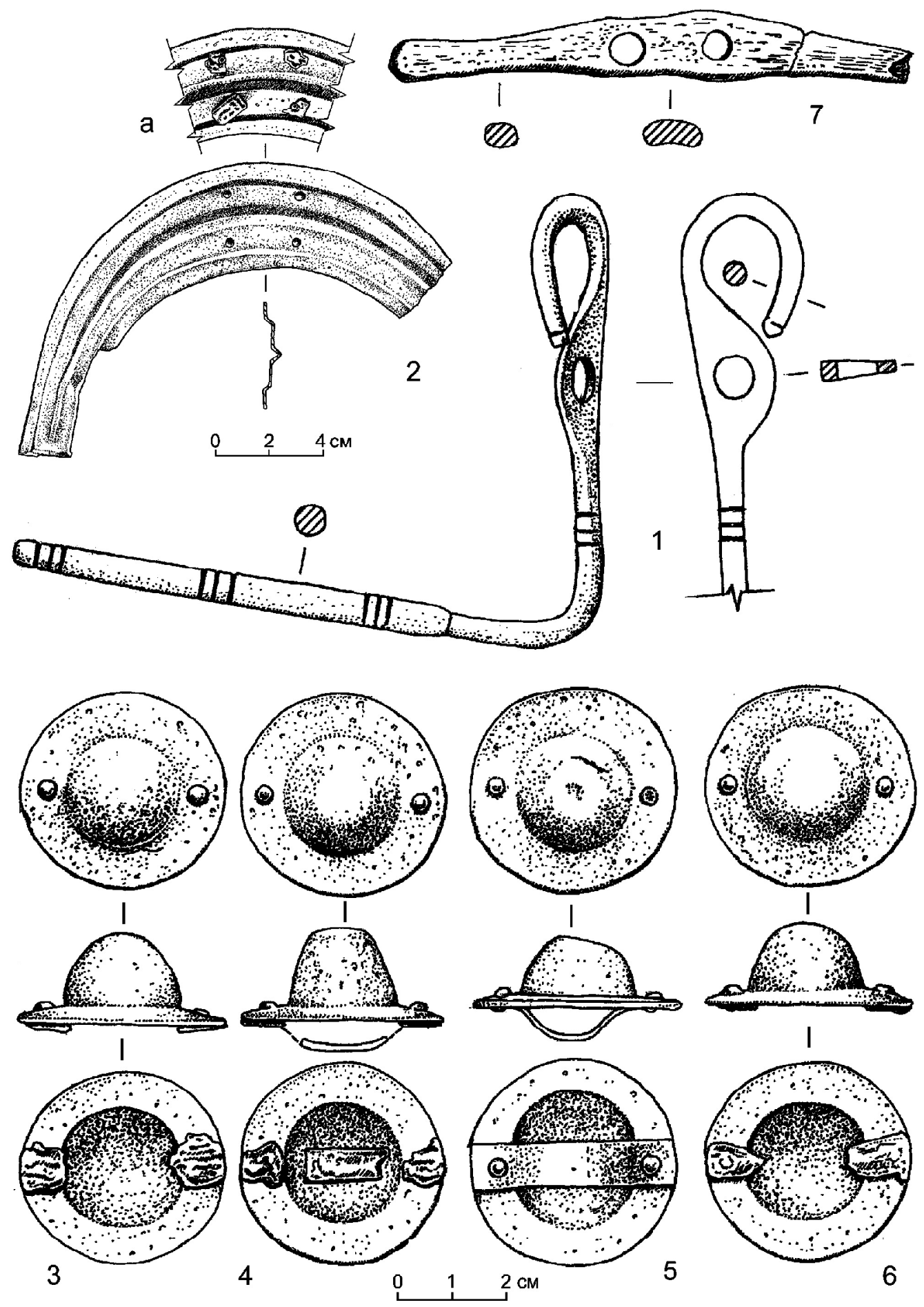

Рис. 2. Ритуальный депозит из кургана 13 (рис. Н.Е. Беспалой):

1 - налобник с крючком; 2 - подвеска науза; 3-6 - бляхи узды; 7 - костяной псалий

Fig. 2. Ritual deposit from barrow 13 (drawn by Natalia Bespalaya):

1 - frontlet plate with a hook; 2 - neck pendant; $3-6$ - bridle roundels; 7 - bone cheek-piece 


\section{АРХЕОЛОГИЯ РАННЕГО ЖЕЛЕЗНОГО ВЕКА}
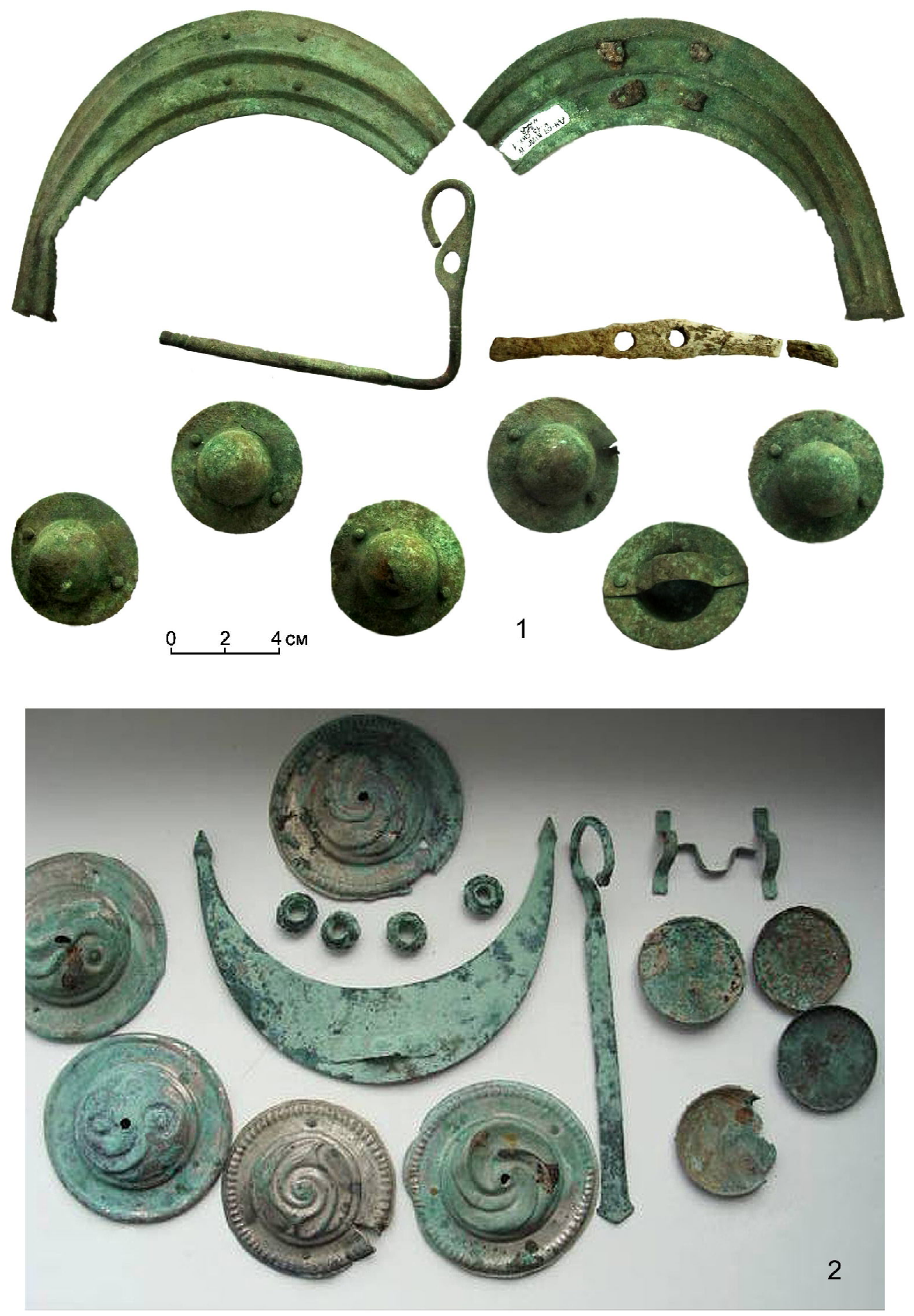

Рис. 3. Ритуальные депозиты:

1 - Красный IV, к. 13 (фото авторов); 2 - аукцион Виолити

Fig. 3. Ritual deposits:

1 - Krasny IV, barrow 13 (photograph by authors); 2 - Violity auction 
М.В. Власкин, А.В. Симоненко. Ритуальный депозит сарматского времени из кургана на Нижнем Дону

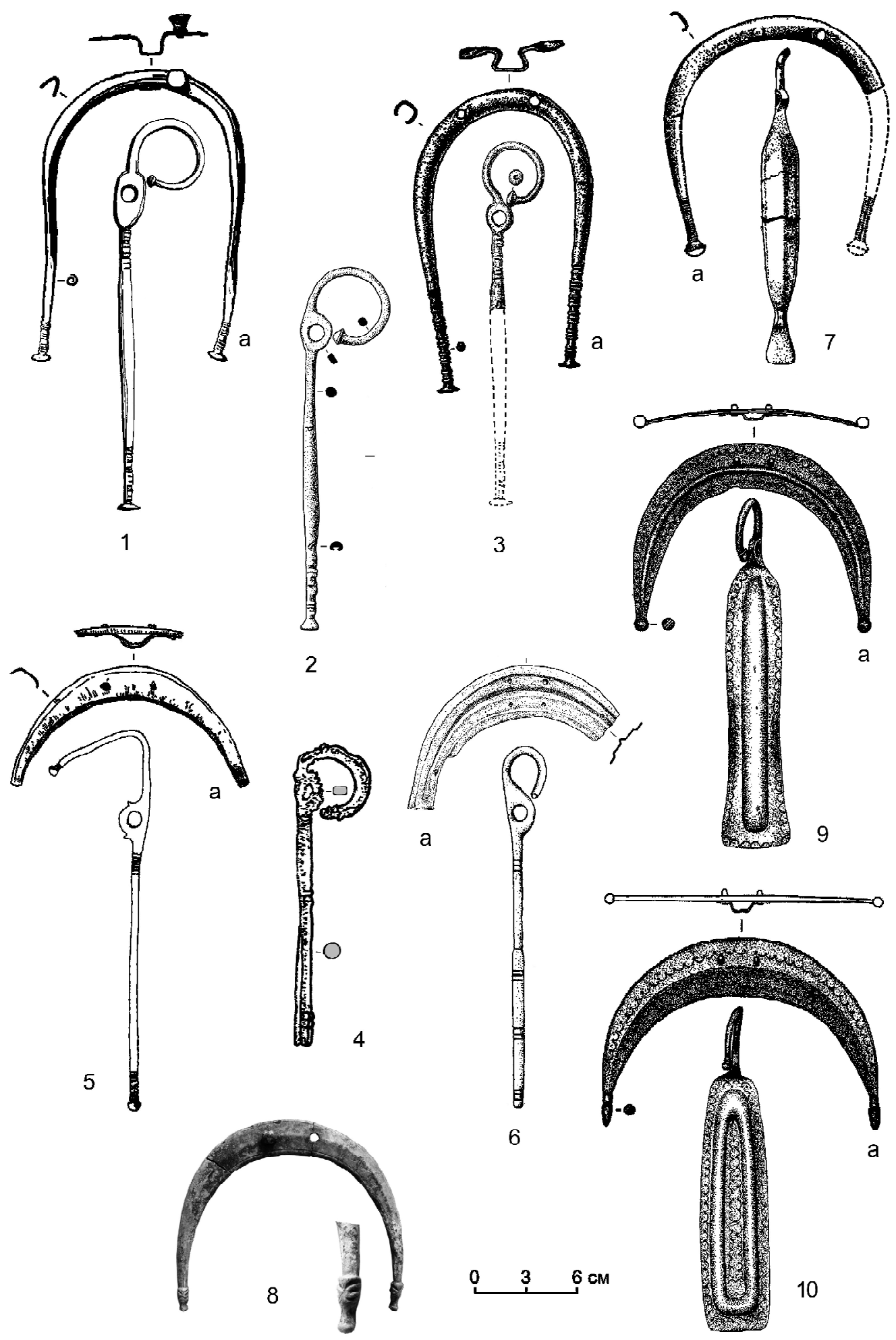

Рис. 4. Налобники и подвески науза (по: [33]):

1, $1 a$ - Марьевка; 2 - Брэвичень; 3, 3a- Прочноокопская; 4 - Геймановский; 5, 5a- Зимнича;

6, 6a- Красный IV (реконструкция); 7, 7a-2-е Ханкальское городище; 8 - Гиагинская; 9, 9a, 10, 10a- Качалинская

Fig. 4. Frontlet plates and neck pendants (after: [33]):

1, $1 a$ - Marievka; 2 - Brrviceni; 3, 3a- Prochnookopskaya; 4- Geimanovski; 5, 5a-Zimnicea;

6, $6 a$ - Krasny IV (reconstructed); 7, 7a-2 ${ }^{\text {nd }}$ Khankalskoe hillfort; 8 - Giaginskaya; 9, 9a, 10, 10a - Kachalinskaya 


\section{АРХЕОЛОГИЯ РАННЕГО ЖЕЛЕЗНОГО ВЕКА}

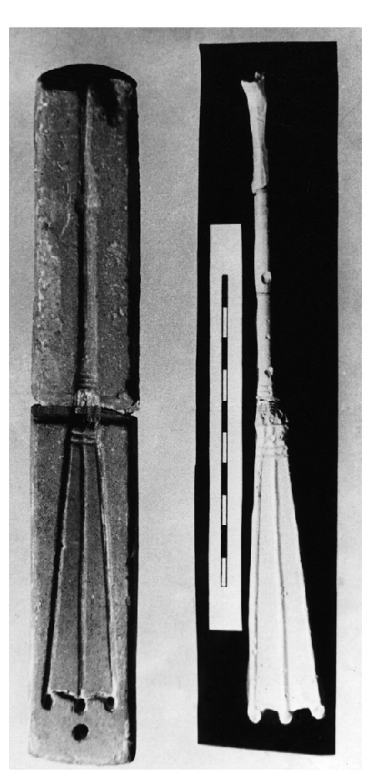

1

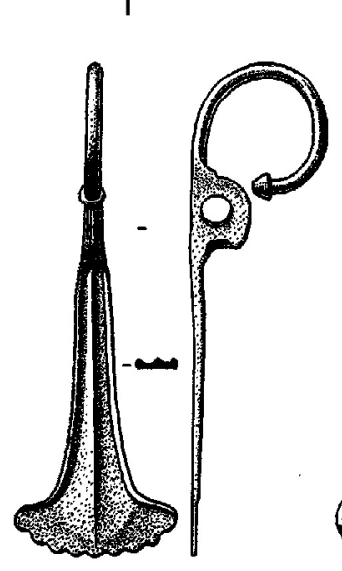

2
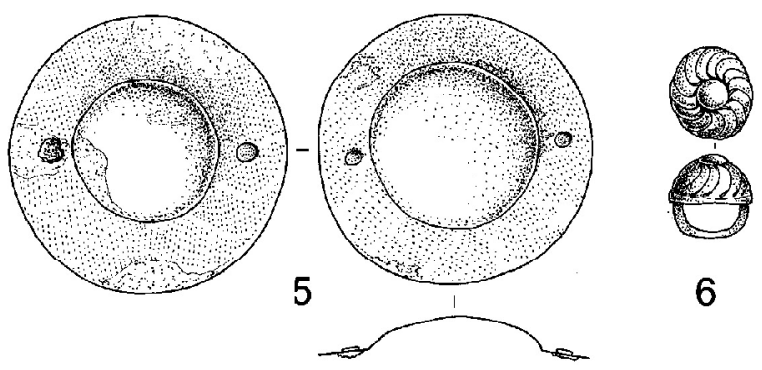

6
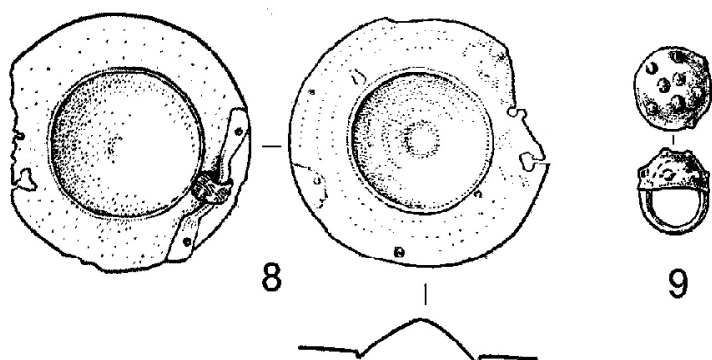

9

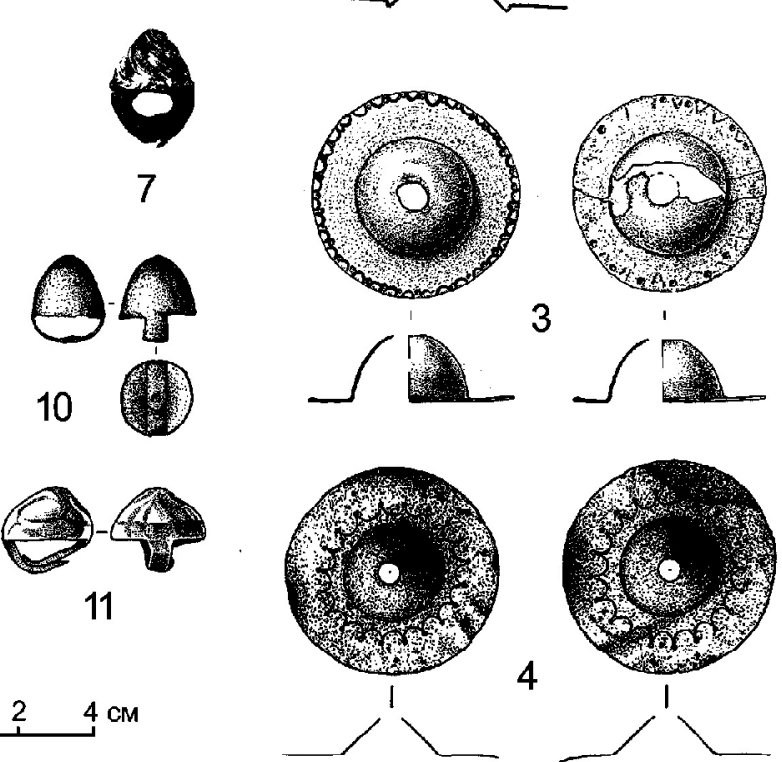

Рис. 5. Конское снаряжение III-І вв. до н.э. (по: [33]):

1 - Неаполь Скифский; 2, 11 - Великоплоское; 3 - Прочноокопская; 4- Качалинская; 5, 6- Горбатый мост; 7 - Васюринская гора; 8,9 - коллекция Платар; 10 - Глиное

Fig. 5. Horse harness of the $3^{\text {rd }}-1^{\text {st }}$ cent. BC (after: [33]):

1 - Scythian Neapolis; 2, 11 - Velikoploskoe; 3 - Prochnookopskaya; 4 - Kachalinskaya; 5, 6 - Gorbaty most; 7 - Vasyurinskaya hill; 8,9- Platar collection; 10 - Glinoe 


\section{СПИСОК ЛИТЕРАТУРЫ}

1. Анфимов, И. Н. Могильник Прочноокопского городища № 3 по материалам архива Н.В. Анфимова / И. Н. Анфимов, А. В. Пьянков // Материалы и исследования по археологии Кубани. - Краснодар : Изд-во КубГУ, 2006. - Вып. 6. - С. 205-228.

2. Анфимов, Н. В. Катакомбные погребения Прочноокопского могильника / Н. В. Анфимов // Методика исследования и интерпретация археологических материалов Северного Кавказа. - Орджоникидзе : Ир, 1988. - С. 51-56.

3. Власова, Е. В. Курганы Васюринской горы / Е. В. Власова // Боспорский феномен. Проблемы хронологии и датировки памятников. В 2 ч. Ч. 1 / [редкол.: В. Ю. Зуев (отв. ред.) и др.]. - СПб. : Изд-во ГЭ, 2004. - С. 275-287.

4. Глебов, В. П. О вариантах обряда захоронения «ритуальных кладов» III-І вв. до н. э. / В. П. Глебов // Stratum Plus. - 2016. - № 3. - C. 145-162.

5. Глебов, В. П. Редкая лучковая фибула из сарматского погребения в Краснодарском крае / В. П. Глебов // Из истории культуры народов Северного Кавказа. Вып. 9 / ред. Ю. А. Прокопенко, Т. А. Невская. - Ставрополь : Печ. двор, 2017. - C. 52-56.

6. Гущина, И. И. К вопросу о датировке и этнической принадлежности некоторых впускных захоронений в курганах Прикубанья, исследованных Н. И. Веселовским в 1900 году / И. И. Гущина // История и культура сарматов / отв. ред. А. С. Скрипкин. Саратов : Изд-во СГУ, 1983. - С. 92-98.

7. Дзиговский, А. Н. Очерки истории сарматов Карпато-Днестровских земель / А. Н. Дзиговский. - Одесса : Гермес, 2003. - 239 с.

8. Дзис-Райко, Г. А. Комплекс предметов скифского времени из с. Великоплоское / Г. А. Дзис-Райко, Е. Ф. Суничук // Ранний железный век СевероЗападного Причерноморья / отв. ред. И. Т. Черняков. - Киев : Наукова думка, 1984. - С. 148-161.

9. Зайцев, Ю. П. Крестовидные удила Северного Причерноморья / Ю. П. Зайцев // Четвертая Кубанская археологическая конференция : тез. и докл. / отв. ред. И. И. Марченко. -Краснодар : Символика, 2005. - С. 88-94.

10. Зайцев, Ю. П. Вотивные клады Северо-Западного Причерноморья III-I вв. до н. э. Хронология и культурная принадлежность / Ю. П. Зайцев // Древнее Причерноморье. - Одесса : ФЛП «Фридман А.С.», 2008. - Вып. 8. - С. 146-152.

11. Зайцев, Ю. П. Предметы конской упряжи IIIІ вв. до н. э. в Северном Причерноморье и на Северном Кавказе (сравнительный анализ) / Ю. П. Зайцев // Пятая Кубанская археологическая конференция : материалы конф. / отв. ред. И. И. Марченко. - Краснодар : Символика, 2009. - С. 134-139.
12. Зайцев, Ю.П. Северное Причерноморье в III-II вв. до н. э.: ритуальные клады и археологические культуры (постановка проблемы) / Ю. П. Зайцев // Древности Северного Причерноморья IIIII вв. до н. э. / отв. ред. Н. П. Тельнов. - Тирасполь : Изд-во ПГУ, 2012. - С. 67-73.

13. Зайцев, Ю. П. «Лунницы» в конской узде Северного Причерноморья и Северного Кавказа эллинистического времени / Ю. П. Зайцев // Шестая Кубанская археологическая конференция : материалы конф. / отв. ред. И. И. Марченко. - Краснодар : Экоинвест, 2013. - С. 137-142.

14. Канторович, А. Р. Бронзолитейное искусство VIII-III вв. до н. э. из курганов Адыгеи / А. Р. Канторович, В. Р. Эрлих. - М. : ГМИНВ, 2006. - 232 с.

15. Карнаух, Е. Г. Скифский клад из Дебальцево / Е. Г. Карнаух, В. С. Синика, М. И. Сердюк // Stratum Plus. - 2016. - № 3. - С. 217-240.

16. Марченко, И. И. Сираки Кубани / И. И. Марченко. - Краснодар : Изд-во КубГУ, 1996. - 337 с.

17. Мошкова, М. Г. Памятники прохоровской культуры / М. Г. Мошкова. - М. : Наука, 1963. 56 с. - (Свод археологических источников ; Д1-10).

18. Нефёдова, Е. С. Бубуечский комплекс (история находки и изучения, задачи интерпретации) / Е. С. Нефёдова // Античная цивилизация и варварский мир. В 2 ч. Ч. 2 / отв. ред. Б. А. Раев. Новочеркасск : [б. и.], 1993. - С. 15-20.

19. Новиченкова, Н. Г. Устройство и обрядность святилища у перевала Гурзуфское Седло / Н. Г. Новиченкова. - Ялта : РИО КГГИ, 2002. -215 с.

20. Петренко, В. А. Клад конского снаряжения из раскопок второго Ханкальского городища (Чечено-Ингушетия) / В. А. Петренко // Советская археология. - 1975. - № 4. - С. 256-259.

21. Полин, С. В. От Скифии к Сарматии/ С. В. Полин. -Киев : [б. и.], 1992. -200 с.

22. Полин, С.В. Гордашевский «клад» / С. В. Полин, Е. Г. Карнаух // Древности Северного Причерноморья III-ІІ вв. до н. э. / отв. ред. Н. П. Тельнов. Тирасполь : Изд-во ПГУ, 2012. - С. 134-144.

23. Раев, Б. А. «Странные комплексы»: от эпохи Латена до могилы Неизвестного солдата / Б. А. Раев, А. В. Симоненко // Боспорский феномен: сакральный смысл региона, памятников, находок. Т. 2 / отв. ред. В. Ю. Зуев. -СПб. : Изд-во ГЭ, 2007. -С. 268-273.

24. Раев, Б. А. Этрусско-италийские и кельтские шлемы в Восточной Европе / Б. А. Раев, А. В. Симоненко, М. Ю. Трейстер // Древние памятники Кубани. - Краснодар : [б. и.], 1990. -С. 117-135.

25. Редина, Е. Ф. «Клад» конца II-І в. до н. э. из Веселой Долины в кругу аналогичных древностей Восточной Европы / Е. Ф. Редина, А. В. Симоненко // Материалы и исследования по археологии Кубани. - Краснодар : Изд-во КубГУ, 2002. - Вып. 2. С. 78-96. 
26. Сергацков, И. В. «Клад» II в. до н. э. из окрестностей станицы Качалинской / И. В. Сергацков // Российская археология. - 2009. - № 4. С. $149-159$.

27. Симоненко, А. В. О позднескифских налобниках / А. В. Симоненко // Древности Степной Скифии / отв. ред. А. И. Тереножкин. - Киев : Наукова думка, 1982. - С. 237-245.

28. Симоненко, А. В. Сарматы Таврии / А. В. Симоненко. - Киев : Наукова думка, 1993. - 111 с.

29. Симоненко, А. В. Сарматы Северного Причерноморья: хронология, периодизация и этнополитическая история : дис. ... д-ра ист. наук / Симоненко Александр Владимирович. - Киев, 1999. -412 с.

30. Симоненко, А. В. Конский убор из большого кургана Васюринской горы / А. В. Симоненко // Боспорский феномен: население, языки, контакты : материалы Междунар. науч. конф. (СанктПетербург, 22-25 нояб. 2011 г.) / отв. ред. М. Ю. Вахтина. - СПб. : Нестор-История, 2011. - С. 598-602.

31. Симоненко, А. В. О крестовидных и подковообразных «псалиях» раннесарматского времени / А. В. Симоненко // Труды ГИМ. Вып. 191. Евразия в скифо-сарматское время. Памяти Ирины Ивановны Гущиной. - М. : ГИМ, 2012. - С. 208-216.

32. Симоненко, А. В. Еще раз о налобниках с крючком / А. В. Симоненко // Шестая Международная Кубанская археологическая конференция : материалы конф. / отв. ред. И. И. Марченко. - Краснодар : Экоинвест, 2013.- С. 376-380.

33. Симоненко, А. В. Сарматские всадники Северного Причерноморья / А. В. Симоненко. - 2-е изд. Киев : Видавець Олег Філюк, 2015. - 466 с.

34. Симоненко, А. В. Ритуальный депозит III вв. до н. э. из Брэвичень / А. В. Симоненко // Revista Arheologică. - 2020. - № 1. - С. 108-120.

35. Скрипкин, А. С. Анализ сарматских погребальных памятников III-І вв. до н. э. / А. С. Скрипкин // Статистическая обработка погребальных памятников Азиатской Сарматии. Вып. 2. Раннесарматская культура (IV-I вв. до н. э.) / отв. ред. М. Г. Мошкова. - М. : ИА РАН, 1997. - С. 131-312.

36. Смирнов, К. Ф. Сарматы и утверждение их политического господства в Скифии / К. Ф. Смирнов. - М. : Наука, 1984. - 181 с.

37. Тельнов, Н. П. Скифский могильник IIIII вв. до н. э. у с. Глиное / Н. П. Тельнов, И. А. Четвериков, В. С. Синика. - Тирасполь : Stratum Plus, 2016. $-1096 \mathrm{c}$.

38. Теодосиев, Н. Тракийски могили от късноелинистическата епоха при Търнава, Белослатинско / Н. Теодосиев, Н. Торбов // Известия на музеите в северозападна България. - Враца : Исторически музей - Враца, 1995. - Т. 23. - С. 11-58.

39. Щукин, М. Б. На рубеже эр. Опыт историкоархеологической реконструкции политических собы- тий III в. до н. э. - І в. н. э. в Восточной и Центральной Европе / М. Б. Щукин. - СПб. : Фарн, 1994. - 323 с.

40. Яровой, Е. В. К вопросу о культурной принадлежности памятников Тираспольской группы (в свете исследований могильника у с. Глиное) / Е. В. Яровой, И. А. Четвериков // Чобручский археологический комплекс и древние культуры Поднестровья (материалы полевого семинара) / отв. ред. Е. В. Яровой. - Тирасполь : Изд-во ПГУ, 2000. - С. 3-28.

41. Alexandrescu, A. D. Tombes de chevaux et pièces du harnais dans la nékropole Gète de Zimnicea / A. D. Alexandrescu // Dacia. - 1983. Vol. 27, Nos. 1/2. - P. 67-78.

42. Bârcâ V. Câteva observații cu privere la tezaurele şi depozitele sarmatice timpurii (sec. II-Ia. Chr.) din spațiul dintre Don şi Prut / V. Bârcâ // Studia Historica et Archaeologica. In Honorem Magistrae Doina Benea. Timişoara : Eurostampa, 2004. - P. 35-63.

43. Raev B. A. Etrusco-Italic and Celtic Helmets in Eastern Europe/ B. A. Raev, A. V. Simonenko, M. Ju. Treister // Jahrbuch des Römisch-Germanisch Zentralmuseums Mainz.-1991.-Bd.38(2).-S.465-496.

\section{REFERENCES}

1. Anfimov I.N., Pyankov A.V. Mogilnik Prochnookopskogo gorodishcha № 3 po materialam arkhiva N.V. Anfimova [The Cemetery of Prochnookopskaya Hill-fort No. 3 According to Archive of Nikita Anfimov]. Materialy i issledovaniya po arkheologii Kubani [Materials and Research of Kuban Region Archaeology]. Krasnodar, Izd-vo KubGU, 2006, iss. 6, pp. 205-228.

2. Anfimov N.V. Katakombnye pogrebeniya Prochnookopskogo mogilnika [Catacomb Graves of Prochnookopskaya Cemetery]. Metodika issledovaniya i interpretatsiya arkheologicheskikh materialov Severnogo Kavkaza [Methods of Research and Interpretation of Archaeological Materials of Northern Caucasus]. Ordzhonikidze, Ir Publ., 1988. pp. 51-56.

3. Vlasova E.V. Kurgany Vasyurinskoy gory [Barrows of Vasyurinskaya Hill]. Zuev V.Yu., ed. Bosporskiy fenomen. Problemy khronologii i datirovki pamyatnikov. V 2 ch. Ch. 1 [The Bosporan Phenomena. Problems of Chronology and Dating of Sites. In 2 Parts. Part 1]. Saint Petersburg, Izd-vo GE, pp. 275-287.

4. Glebov V.P. O variantakh obryada zakhoroneniya «ritualnykh kladov» III-I vv. do n. e. [On the Variants of the Rite of Deposit of "Ritual Hoards" of the $3^{\text {rd }}-1^{\text {st }}$ Cent. BC]. Stratum Plus, 2016, no. 3, pp. 145-162.

5. Glebov V.P. Redkaya luchkovaya fibula iz sarmatskogo pogrebeniya v Krasnodarskom krae [Rare 
Bow-Shaped Fibula from the Sarmatian Burial in Krasnodar Krai]. Iz istorii kultury narodov Severnogo Kavkaza. Vyp. 9 [From the Cultural History of the Peoples of the North Caucasus. Iss. 9]. Stavropol, Pechatnyy dvor, 2017, pp. 52-56.

6. Gushchina I.I. K voprosu o datirovke i etnicheskoy prinadlezhnosti nekotorykh vpusknykh zakhoroneniy v kurganakh Prikubanya, issledovannykh N.I. Veselovskim v 1900 godu [Case Study on the Date and Ethnic Belonging of Some Graves Inserted into Barrows of Kuban Region, Excavated by Nikolai Veselovski in 1900]. Skripkin A.S., ed. Istoriya i kultura sarmatov [The History and culture of the Sarmatians]. Saratov, Izd-vo SGU, 1983, pp. 92-98.

7. Dzigovskiy A.N. Ocherki istorii sarmatov Karpato-Dnestrovskikh zemel [Issue on the History of Sarmatians of Carpathian-Dniester Basin]. Odessa, Germes Publ., 2003. 239 p.

8. Dzis-Rayko G.A., Sunichuk E.F. Kompleks predmetov skifskogo vremeni iz s. Velikoploskoe [The Assemblage of the Scythian Age from Velikoploskoe Village]. Chernyakov I.T., ed. Ranniy zheleznyy vek Severo-Zapadnogo Prichernomorya [Early Iron Age of the North-Western Pontic Region]. Kiev, Naukova dumka Publ., 1984, pp. 148-161.

9. Zaytsev Yu.P. Krestovidnye udila Severnogo Prichernomorya [The Cross-Shaped Bits of the North Pontic Region]. Chetvertaya Kubanskaya arkheologicheskaya konferentsiya: tez. $i$ dokl. [ $4^{\text {th }}$ Kuban Archaeological Conference. Abstracts]. Krasnodar, Simvolika Publ., 2005, pp. 88-94.

10. Zaytsev Yu.P. Votivnye klady SeveroZapadnogo Prichernomorya III-I vv. do n. e. Khronologiya i kulturnaya prinadlezhnost [Votive Hoards of the $3^{\text {rd }}-1^{\text {st }}$ Cent. BC in the North-Western Pontic Region. Chronology and Cultural Belong]. Drevnee Prichernomorye [Ancient Northern Pontic Region]. Odessa, FLP «Fridman A.S.», 2008, iss. 8, pp. 146-152.

11. Zaytsev Yu.P. Predmety konskoy upryazhi IIII vv. do n. e. v Severnom Prichernomorye i na Severnom Kavkaze (sravnitelnyy analiz) [Horse Harness of the $3^{\text {rd }}$ $1^{\text {st }}$ Cent. BC in the Northern Pontic Region and Northern Caucasus (Comparative Analysis)]. Pyataya Kubanskaya arkheologicheskaya konferentsiya: materialy konf. [5 ${ }^{\text {th }}$ Kuban Archaeological Conference. Abstracts]. Krasnodar, Simvolika Publ., 2009, pp. 134-139.

12. Zaytsev Yu.P. Severnoe Prichernomorye v IIIII vv. do n. e.: ritualnye klady i arkheologicheskie kultury (postanovka problemy) [Northern Pontic Region in the $3^{\text {rd }}-2^{\text {nd }}$ Cent. BC: Ritual Hoards and Archaeological Cultures (Problem Statement)]. Telnov N.P., ed. Drevnosti Severnogo Prichernomorya III-II vv. do n.e. [Northern Pontic antiquities of the $3^{\text {rd }}$ $-2^{\text {nd }}$ cent. BC]. Tiraspol, Izd-vo PGU, 2012, pp. 67-73.
13. Zaytsev Yu.P. «Lunnitsy» v konskoy uzde Severnogo Prichernomorya i Severnogo Kavkaza ellinisticheskogo vremeni ["Lunalae" in the Horse Harness of the Northern Pontic Region and Northern Caucasus of the Hellenistic Age]. Shestaya Kubanskaya arkheologicheskaya konferentsiya: materialy konf. [ $6^{\text {th }}$ Kuban Archaeological Conference. Abstracts]. Krasnodar, Ekoinvest Publ., 2013, pp. 137-142.

14. Kantorovich A.R. Bronzoliteynoe iskusstvo VIII-III vv. do n. e. iz kurganov Adygei [Bronze Casting of the $8^{\text {th }}-3^{\text {rd }}$ Cent. BC from Adygean Barrows]. Moscow, GMINV, 2006. 232 p.

15. Karnaukh E.G. Skifskiy klad iz Debaltsevo [Scythian Hoard from Debaltsevo]. Stratum Plus, 2016, no. 3, pp. 217-240.

16. Marchenko I.I. Siraki Kubani [The Siraci of Kuban Basin]. Krasnodar, Izd-vo KubGU, 1996. 337 p.

17. Moshkova M.G. Pamyatniki prokhorovskoy kultury [Sites of the Prokhorovka Culture]. Moscow, Nauka Publ., 1963. 56 p. (Svod arkheologicheskikh istochnikov [Set of Archaeological Sources], D1-10).

18. Nefedova E.S. Bubuechskiy kompleks (istoriya nakhodki i izucheniya, zadachi interpretatsii) [Assemblage from Bubuieci (History of Find and Study, Intepretation Tasks]. Antichnaya tsivilizatsiya $i$ varvarskiy mir. V2 ch. Ch. 2 [Classic Civilization and Barbarian World. In 2 Parts. Part 2]. Novocherkassk, [s.n.], 1993, pp. 15-20.

19. Novichenkova N.G. Ustroystvo i obryadnost svyatilishcha u perevala Gurzufskoe Sedlo [Construction and Rite of the Sanctuary on the Gurzufskoe Sedlo Pass]. Yalta, RIO KGGI, 2002. 215 p.

20. Petrenko V.A. Klad konskogo snaryazheniya iz raskopok vtorogo Khankalskogo gorodishcha (Checheno-Ingushetiya) [Horse Harness Hoard from the Second Khankala Hillfort Excavation]. Sovetskaya arkheologia, 1975, no. 4, pp. 256-259.

21. Polin S.V. Ot Skifii $k$ Sarmatii [From Scythia to Sarmatia]. Kiev, [s.n.], 1992. 200 p.

22. Polin S.V., Karnaukh E.G. Gordashevskiy «klad» [Gordashevka "Hoard"]. Drevnosti Severnogo Prichernomorya III-II vv. do n. e. [Northern Pontic Antiquities of the $3^{\text {rd }}-2^{\text {nd }}$ Cent. BC]. Tiraspol, Izd-vo PGU, 2012, pp. 134-144.

23. Raev B.A., Simonenko A.V. «Strannye kompleksy»: ot epokhi Latena do mogily Neizvestnogo soldata ["Strange Assemblages": Since La-Tène Epoch till the Burial of Unknown Soldier]. Bosporskiy fenomen: sakralnyy smysl regiona, pamyatnikov, nakhodok. T. 2 [Bosporan Phenomena: The Sacral Sense of the Region, Sites, Finds. Vol. 2]. Saint Petersburg, Izd-vo GE, 2007, pp. 268-273.

24. Raev B.A., Simonenko A.V., Treyster M.Yu. Etrussko-italiyskie i keltskie shlemy v Vostochnoy Evrope [Etruscan-Italic and Celtic Helmets in Eastern Europe]. Drevnie pamyatniki Kubani 
[Ancient Sites of the Kuban Region]. Krasnodar, [s. n.], 1990, pp. 117-135.

25. Redina E.F., SimonenkoA.V. «Klad» kontsa III v. do n. e. iz Veseloy Doliny v krugu analogichnykh drevnostey Vostochnoy Evropy ["Hoard" of the Late $2^{\text {nd }}-1^{\text {st }}$ Cent. BC from Veselaya Dolina Village in the Circle of the Similar Antiquities of Eastern Europe]. Materialy $i$ issledovaniya po arkheologii Kubani [Materials and Research on the Archaeology of the Kuban Region]. Krasnodar, Izd-vo KubGU, 2002, iss. 2, pp. 78-96.

26. Sergatskov I.V. «Klad» II v. do n. e. iz okrestnostey stanitsy Kachalinskoy ["Hoard" of the $2^{\text {nd }}$ Cent. BC. from Stanitsa Kachalinskaya Outskirts]. Rossiyskaya arkheologiya [Russian Archaeology], 2009, no. 4, pp. 149-159.

27. Symonenko A.V. O pozdneskifskikh nalobnikakh [On the Late Scythian Frontlet Plates]. Drevnosti Stepnoy Skifii [Steppe Scythia Antiquities]. Kiev, Naukova dumka Publ., 1982, pp. 237-245.

28. SymonenkoA.V. Sarmaty Tavrii [The Sarmatians of Tauria]. Kiev, Naukova dumka Publ., 1993. 111 p.

29. Symonenko A.V. Sarmaty Severnogo Prichernomorya: khronologiya, periodizatsiya $i$ etnopoliticheskaya istoriya: dis. ... d-ra ist. nauk [The Sarmatians of the Northern Pontic Region: Chronology, Periodization and Ethno-Political History. Dr. hist. sci. diss.]. Kiev, 1999. 412 p.

30. Symonenko A.V. Konskiy ubor iz bolshogo kurgana Vasyurinskoy gory [Horse Harness From the Large Barrow of Vasyurinskaya Hill]. Bosporskiy fenomen: naselenie, yazyki, kontakty: materialy Mezhdunar. nauch. konf. (Sankt-Peterburg, 22-25 noyab. 2011 g.) [Bosporan Phenomena: Population, Languages, Contacts: Proceedings of the International Scientific Conference (Saint Petersburg, November 22-25, 2011)]. Saint Petersburg, Nestor-Istoriya Publ., 2011, pp. 598-602.

31. Symonenko A.V. O krestovidnykh i podkovoobraznykh «psaliyakh» rannesarmatskogo vremeni [On the Cross-Shaped and Arch-Shaped "Check-Pieces" of the Early Sarmatian Age]. Trudy GIM. Vyp. 191. Evraziya v skifo-sarmatskoe vremya. Pamyati Iriny Ivanovny Gushchinoy [Transactions of State Historical Museum. Eurasia in the ScythianSarmatian Age. In Memoriam of Irina Gushchina]. Moscow, GIM, 2012, pp. 208-216.

32. Symonenko A.V. Eshche raz o nalobnikakh s kryuchkom [Case Study on the Frontlet Plates with a Hook]. Shestaya Mezhdunarodnaya Kubanskaya arkheologicheskaya konferentsiya: materialy konf. [6 $6^{\text {th }}$ International Kuban Region Archaeological Conference. Proceedings]. Krasnodar, Ekoinvest Publ., 2013, pp. 376-380.

33. Symonenko A.V. Sarmatskie vsadniki Severnogo Prichernomoria [Sarmatian horsemen of Northern Pontic region]. Kiev, Vydavets Oleh Filyuk, 2015.466p.
34. Symonenko A.V. Sarmatskie vsadniki Severnogo Prichernomorya [Ritual Deposit of the $2^{\text {nd }}-$ $1{ }^{\text {st }}$ Cent. BC from Brãviceni]. Revista Arheologică, 2020, no. 1 (to appear).

35. Skripkin A.S. Analiz sarmatskikh pogrebalnykh pamyatnikov III-I vv. do n. e. [Analysis of Sarmatian Funeral Sites of the $3^{\text {rd }}-1^{\text {st }}$ Cent. BC]. Statisticheskaya obrabotka pogrebalnykh pamyatnikov Aziatskoy Sarmatii. Vyp. 2. Rannesarmatskaya kultura (IV-Ivv. do n. e.) [Statistical Processing of the Funeral Sites of Asian Sarmatia. Iss. 2. Early Sarmatian Culture ( $4^{\text {th }}-$ $1^{\text {st }}$ Cent. BC)]. Moscow, IARAN, 1997, pp. 131-312.

36. Smirnov K.F. Sarmaty i utverzhdenie ikh politicheskogo gospodstva $v$ Skifii [Sarmatians and the Establishment of Their Political Domination in Scythia]. Moscow, Nauka Publ., 1984. 181 p.

37. Telnov N.P., Chetverikov I.A., Sinika V.S. Skifskiy mogilnik III-II vv. do n. e. us. Glinoe [Scythian Cemetery of the $3^{\text {rd }}-2^{\text {nd }}$ Cent. BC near Glinoe Village]. Tiraspol, Stratum Plus, 2016. 1096 p.

38. Teodosiev N., Torbov N. Trakiyski mogili ot kysnoelinisticheskata epokha pri Tyrnava, Beloslatinsko [Tracian Graves of the Late Hellenistic Age near Trnava of Beloslatinski District]. Izvestiya na muzeite $v$ severozapadna Bylgariya [Transactions of the Western Bulgaria Museum]. Vratsa, Istoricheski muzey-Vratsa, 1995, vol. 23, pp. 11-58.

39. Shchukin M.B. Na rubezhe er. Opyt istorikoarkheologicheskoy rekonstruktsii politicheskikh sobytiy III v. do n. e. -Iv.n. e. v Vostochnoy i Tsentralnoy Evrope [On the Turn of Era. The Attempt of Historical and Archaeological Reconstruction of the Political Affairs of the $3^{\text {rd }}$ Cent. BC $-1{ }^{\text {st }}$ Cent. AD in the Eastern and Central Europe]. Saint Petersburg, Farn Publ., 1994. 323 p.

40. Yarovoy E.V., Chetverikov I.A. K voprosu o kulturnoy prinadlezhnosti pamyatnikov Tiraspolskoy gruppy (v svete issledovaniy mogilnika u s. Glinoe) [Case Study of the Cultural Belonging of the Sites of Tiraspol Group (In the Light of the Research of Glinoe Cemetery)]. Chobruchskiy arkheologicheskiy kompleks $i$ drevnie kultury Podnestrovya (materialy polevogo seminara) [Archaeological Complex in Cioburciu and Prehistoric Cultures of Dniester Basin (Proceedings of the Field Seminar)]. Tiraspol, Izd-vo PGU, 2000, pp. 3-28.

41. Alexandrescu A.D. Tombes de chevaux et pièces du harnais dans la nékropole Gète de Zimnicea. Dacia, 1983, vol. 27, nos. 1/2, pp. 67-78.

42. Bârcâ V. Câteva observații cu privere la tezaurele şi depozitele sarmatice timpurii (sec. II-I a. Chr.) din spațiul dintre Don şi Prut. Studia Historica et Archaeologica. In Honorem Magistrae Doina Benea. Timişoara, Eurostampa, 2004, pp. 35-63.

43. Raev B.A., Simonenko A.V., Treister M.Ju. Etrusco-Italic and Celtic Helmets in Eastern Europe. Jahrbuch des Römisch-Germanisch Zentralmuseums Mainz, 1991, Bd. 38 (2), S. 465-496. 
М.В. Власкин, А.В. Симоненко. Ритуальный депозит сарматского времени из кургана на Нижнем Дону

\section{Information About the Authors}

Mikhail V. Vlaskin, Director, State Autonomic Cultural Facility of Rostov Region "The Don Heritage", Nizhnebulvarnaya St, 29, 344022 Rostov-on-Don, Russian Federation, nasledie_don@mail.ru, https://orcid.org/0000-0002-7951-8915

Aleksandr V. Symonenko, Dr. habil., Chief Research Fellow, Early Iron Age Department, Institute of Archaeology of National Academy of Sciences of Ukraine, Prosp. Heroiv Stalinhrada, 12, 04210 Kyiv, Ukraine, simonal@ukr.net, https://orcid.org/0000-0001-6878-556X

\section{Информация об авторах}

Михаил Васильевич Власкин, директор, Государственное автономное учреждение культуры Ростовской области «Донское наследие», ул. Нижнебульварная, 29, 344022, г. Ростов-наДону, Российская Федерация, nasledie_don@mail.ru, https://orcid.org/0000-0002-7951-8915

Александр Владимирович Симоненко, доктор исторических наук, ведущий научный сотрудник отдела археологии раннего железного века, Институт археологии Национальной академии наук Украины, просп. Героев Сталинграда, 12, 04210 г. Киев, Украина, simonal@ukr.net, https://orcid.org/0000-0001-6878-556X 